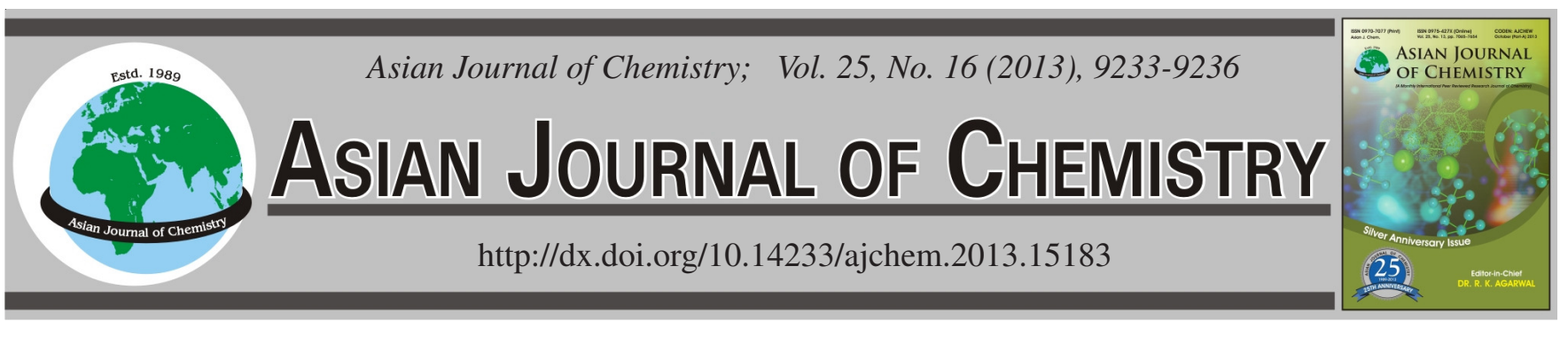

\title{
A Convenient Synthesis and Antimicrobial Activity of Functionalized 1,2,4-Triazoles and 3-Amino-alkyltetraazabicyclo[3.3.0]octan-8-ones
}

\author{
Abdullah Sulaiman Al-Ayed ${ }^{1}$ and Khaireddine Mohamed Dridi ${ }^{1,2, *}$
}

\begin{abstract}
${ }^{1}$ Department of Chemistry, College of Sciences and Atrs at Al-Rass, Qassim University, P.O. Box 53, Kingdom of Saudi Arabia
\end{abstract} ${ }^{2}$ Department of Chemistry, College of Sciences at Tunis, El Manar University, Tunis, Tunisia

*Corresponding author: E-mail: khairydridi@yahoo.fr

(Received: 21 January 2013;

Accepted: 20 September 2013)

AJC-14151

\begin{abstract}
5-Amino-1,2,4-triazole derivatives and their bicyclic system were synthesized in moderate to good yields from the corresponding $\alpha$-aminoesters, hydrazine or methylhydrazine and the starting material dimethyl N-cyanodithioiminocarbonate. Many target compounds were obtained. But, in cases when the bicyclic system is not formed, 5-amino-1,2,4-triazoles are usually formed. Structures of the prepared compounds were elucidated on the basis of their spectral data and their antifungal and antibacterial activities were also evaluated.
\end{abstract}

Key Words: N-Cyano-N'(alcoxycarboxylalkyl)thioimidates, 5-Amino-1,2,4-triazoles, Tetraazabicyclo[3.3.0]octan-8-ones.

\section{INTRODUCTION}

Recently, the literature has reported a large number of 1,2,4-triazoles containing ring systems that have incorporated into a wide variety of therapeutically interesting drugs including anticancer $^{1,2}$, antifungal ${ }^{3-5}$, antibacterial and antimicrobial properties $^{6-10}$. Owing to all these potential properties, we established a research program that focused on the synthesis of new triazoles and substituted tetraazabicyclo[3.3.0] octanones and resulted in the discovery of a simple and general route for the preparation of functionalized 5-amino-1,2,4-triazoles $(\mathbf{3}, \mathbf{6}$ and 7) and 3-aminoalkyltetraazabicyclo[3.3.0] octan-8-ones (5) starting from N-cyano-N'(alcoxycarboxyl alkyl)thioimidates (2).

\section{EXPERIMENTAL}

Melting points were taken with a Kofler hot staged apparatus and are uncorrected. All reactions were monitored by thin layer chromatography (TLC). IR spectra were determined with a Perkin Elmer 1600 series FTIR spectrometer. Mass spectra were recorded on a Varian Mat 311 Mass Spectrometer. ${ }^{1} \mathrm{H}$ and ${ }^{13} \mathrm{C}$ NMR spectra were recorded on a VarianUnity spectro-meter at $300 \mathrm{MHz}$ using TMS as an internal standard. The starting material dimethyl N-cyanodithioamidocarbonate (1) was prepared by published method in literature $^{11}$. The bacterial strains and Aspergillus Niger fungus were obtained from the Centre of the agro food of Tunis (Tunisia).
Synthesis of methyl N-cyano-N'(1-methoxycarbonyl alkyl)thioimidates (2): Dimethyl $\mathrm{N}$-cyanodithioamidocarbonate was added to a stirred suspension of $\alpha$-aminoester hydrochloride $(10 \mathrm{mmol})$ and triethylamine $(12 \mathrm{mmol})$ in 50 $\mathrm{mL}$ of absolute ethanol. The resulting solution was heated to reflux for $8 \mathrm{~h}$. The solvent was removed under vacuum and the residue dissolved in chloroform $(40 \mathrm{~mL})$ and washed with saturated sodium bicarbonate solution $(2 \times 25 \mathrm{~mL})$. The organic layer was dried with $\mathrm{MgSO}_{4}$ and the solvent was removed under vacuum. The residue was chromatographed on silica gel, eluting with chloroform, $20 \%$ ethanol to give the product oil 2.

2a: Yield: $66 \%$. ${ }^{1} \mathrm{H}$ NMR (DMSO- $\left.d_{6}+\mathrm{CDCl}_{3}\right): 5.87(\mathrm{~s}$, br, $1 \mathrm{H}), 3.81(\mathrm{~s}, 3 \mathrm{H}), 3.87(\mathrm{~m}, 2 \mathrm{H}), 2.31(\mathrm{~s}, 3 \mathrm{H}) ;{ }^{13} \mathrm{C} \mathrm{NMR}$ $\left(\mathrm{DMSO}-d_{6}+\mathrm{CDCl}_{3}\right) \delta: 168.1,163.2,114.5,51.3,38.8,17.8$; IR $\left(\mathrm{CHCl}_{3}, v_{\max }, \mathrm{cm}^{-1}\right): 3438,2191,1733,1633$.

2b: Yield: $72 \%$. ${ }^{1} \mathrm{HNMR}$ (DMSO- $\left.d_{6}+\mathrm{CDCl}_{3}\right): 6.32(\mathrm{~s}$, br, $1 \mathrm{H}), 4.01(\mathrm{~m}, 1 \mathrm{H}), 3.83(\mathrm{~s}, 3 \mathrm{H}), 1.31(\mathrm{~d}, 3 \mathrm{H}, J=7.5 \mathrm{~Hz}) ;{ }^{13} \mathrm{C}$ NMR (DMSO- $d_{6}+\mathrm{CDCl}_{3}$ ) $\delta: 167.9,163.1,114.4,50.8,42.3$, 18.2, 17.7; IR $\left(\mathrm{CHCl}_{3}, v_{\max }, \mathrm{cm}^{-1}\right): 3435,2912,1735,1632$.

2c: Yield: $63 \% .{ }^{1} \mathrm{H}$ NMR (DMSO- $d_{6}+\mathrm{CDCl}_{3}$ ): 6.63 (s, br, $1 \mathrm{H}), 4.31(\mathrm{~m}, 1 \mathrm{H}), 3.81(\mathrm{~s}, 3 \mathrm{H}), 2.33(\mathrm{~s}, 3 \mathrm{H}), 1.83(\mathrm{~m}, 2 \mathrm{H}), 1.02(\mathrm{t}$, $3 \mathrm{H}, J=7.4 \mathrm{~Hz}$ ); ${ }^{13} \mathrm{C}$ NMR (DMSO- $\left.d_{6}+\mathrm{CDCl}_{3}\right) \delta: 167.2,162.9$, 114.5, 51.2, 42.3, 17.7, 16.9, 9.8; IR $\left(\mathrm{CHCl}_{3}, v_{\max }, \mathrm{cm}^{-1}\right): 3442$, 2187, 1730,1644.

2d: Yield: $67 \%$. ${ }^{1} \mathrm{HNMR}$ (DMSO- $\left.d_{6}+\mathrm{CDCl}_{3}\right): 7.42-7.12$ $(\mathrm{m}, 5 \mathrm{H}), 6.57(\mathrm{~s}, \mathrm{br}, 1 \mathrm{H}), 5.22(\mathrm{~s}, 2 \mathrm{H}), 4.23(\mathrm{~m}, 1 \mathrm{H}), 2.41(\mathrm{~s}$, $3 \mathrm{H}), 1.85(\mathrm{~m}, 2 \mathrm{H}), 0.95(\mathrm{t}, 3 \mathrm{H}, J=7.5 \mathrm{~Hz}) ;{ }^{13} \mathrm{C}$ NMR (DMSO- 
$\left.d_{6}+\mathrm{CDCl}_{3}\right) \delta: 168.2,163.1,130.7,129.6,127.8,126.4,121.2$, 114.4, 55.2, 52.8, 24.6, 17.9, 10.1; IR $\left(\mathrm{CHCl}_{3}, \nu_{\max }, \mathrm{cm}^{-1}\right): 3437$, 2198, 1742, 1635, 1568, 1218.

2e: Yield: $49 \%,{ }^{1} \mathrm{H}$ NMR (DMSO- $\left.d_{6}+\mathrm{CDCl}_{3}\right)$ : 7.45$7.04(\mathrm{~m}, 10 \mathrm{H}), 6.63(\mathrm{~s}, \mathrm{br}, 1 \mathrm{H}), 5.23(\mathrm{~s}, 2 \mathrm{H}), 4.21(\mathrm{~m}, 7 \mathrm{H})$, 2.41(m, 2H), 2.23(m, 2H); $\left.{ }^{13} \mathrm{C} \mathrm{NMR} \mathrm{(DMSO-} d_{6}+\mathrm{CDCl}_{3}\right) \delta$ : 170.1, 162.9, 130.8, 130.2, 129.4, 127.8, 126.4, 121.2, 120.4, $114.5,60.1,53.2,28.7,17.8 ; \mathrm{IR}\left(\mathrm{CHCl}_{3}, \mathrm{v}_{\max }, \mathrm{cm}^{-1}\right): 3432$, 2192, 1739, 1633, 1562, 1220, 1218.

\section{Synthesis of aminotriazoles (3)}

General procedure: A solution of $2(1.15 \mathrm{mmol})$ and hydrazine monohydrate $(1.15 \mathrm{mmol})$ in isopraopanol $(20 \mathrm{~mL})$ was boiled under reflux for $7 \mathrm{~h}$. The solvent was removed by evaporation under vacuum. Petroleum ether was added and the mixture was allowed to cool. The resulting precipitation was collected by filtration, washed with ether and dried as $\mathbf{3}$.

3a: Yield: $92 \%$. m.p. $160-162{ }^{\circ} \mathrm{C} .{ }^{1} \mathrm{H}$ NMR (DMSO- $d_{6}$ ): 10.73 (s, br, 1H), 5.65(s, br, 1H), 5.05(s, br, 1H), 3.76(d, 2H, $J=6 \mathrm{~Hz}), 3.59(\mathrm{~s}, 3 \mathrm{H}) ;{ }^{13} \mathrm{C}$ NMR (DMSO- $\left.d_{6}\right) \delta: 172.1,161.4$, 156.1, 51.4, 44.2; IR $\left(\mathrm{KBr}, \mathrm{v}_{\max }, \mathrm{cm}^{-1}\right)$ : 3406, 3340, 3302, 3090, 1729, 1652, 1577, 1392, 1222; MS (m/z) 172, 171, 139, 131, 119, 112.

3b: Yield: $75 \%$, m.p. $188-190{ }^{\circ} \mathrm{C} .{ }^{1} \mathrm{H}$ NMR (DMSO- $\left.d_{6}\right)$ : $10.63(\mathrm{~s}, \mathrm{br}, 1 \mathrm{H}), 5.85(\mathrm{~s}, \mathrm{br}, 1 \mathrm{H}), 5.52(\mathrm{~s}, \mathrm{br}, 2 \mathrm{H}), 4.02(\mathrm{~m}, 1 \mathrm{H})$, $3.57(\mathrm{~s}, 3 \mathrm{H}), 1.24(\mathrm{~d}, 3 \mathrm{H}, J=7.5 \mathrm{~Hz}) ;{ }^{13} \mathrm{C}$ NMR $\left(\mathrm{DMSO}-d_{6}\right) \delta$ : 174.3, 161.7, 157.4, 51.1, 50.8, 18.2; IR $\left(\mathrm{KBr}, \mathrm{v}_{\max }, \mathrm{cm}^{-1}\right)$ : 3436, 3350, 3284, 3090, 1725, 1654, 1570, 1398, 1112; MS $(\mathrm{m} / \mathrm{z}): 186,153,126$.

3c: Yield: $72 \% .{ }^{1} \mathrm{H}$ NMR (DMSO- $\left.d_{6}\right): 10.72(\mathrm{~s}, 1 \mathrm{H}), 5.75$ (s, br, 1H), 5.62(s, br, 2H), 3.91(m,1H), 3.65(s, 3H), 1.73(m, $2 \mathrm{H}), 0.92(\mathrm{~d}, 3 \mathrm{H}, J=7.6 \mathrm{~Hz}) ;{ }^{13} \mathrm{C}$ NMR (DMSO- $\left.d_{6}\right) \delta: 172.4$, 160.1, 154.2, 55.1, 49.3, 23.0, 8.7; IR (KBr, $\left.v_{\max }, \mathrm{cm}^{-1}\right): 3425$, $3345,3277,3090,1724,1652,1569,1219$; MS (m/z): 200, 199, 170, 140, 126.

3d: Yield: 65. m.p. 163-165 ${ }^{\circ} \mathrm{C} .{ }^{1} \mathrm{H}$ NMR (DMSO- $d_{6}$ ): 10.75 (s, br, 1H), 7.41-7.1(m, 5H), 5.65(s, br, 1H), 5.56(s, br, $2 \mathrm{H}), 5.13$ (s, 2H), 3.90-3.81(s, 3H), 1.72(m, 2H), 0.89(t, 3H, $J=7.6 \mathrm{~Hz}) ;{ }^{13} \mathrm{C}$ NMR (DMSO- $\left.d_{6}\right) \delta: 173.1,159.8,154.3$, 129.7, 127.8, 127.1, 126.8, 121.2, 57.1, 54.2, 24.1, 8.9; IR $\left(\mathrm{KBr}, v_{\max }, \mathrm{cm}^{-1}\right): 3425,3345,3279,3090,1731,1653,1570$, 1220; MS (m/z): 276, 275, 243, 216, 91 .

3e: Yield: $68 \%$. m.p. $137-139{ }^{\circ} \mathrm{C} .{ }^{1} \mathrm{H}$ NMR (DMSO- $\left.d_{6}\right)$ : 10.72 (s, br, 1H), 7.45-7.12(m, 10H), 5.91(s, br, 1H), 5.65(s, br, 2H), 5.22(s, 2H), 4.13(m, 1H), 2.21(m, 2H); ${ }^{13} \mathrm{C}$ NMR (DMSO-d $) \delta: 172.3,160.1,154.6,130.7,130.2,129.6,127.8$, 126.7, 121.2, 120.4, 59.2, 54.6, 27.8; IR (KBr): 3426, 3345, $3277,3089,1725,1654,1568,1545,1219 ; \operatorname{MS}(\mathrm{m} / \mathrm{z}): 338$, 337, 246, 216, 202, 91.

Synthesis of 3-aminotetraazabicyclo[3.3.0]octan-8ones (5c) and (5e) from, respectively compounds (2c) and (2e): A mixture of $\mathbf{2 c}(1.3 \mathrm{mmol})$ and hydrazine monohydrate $(1.6 \mathrm{mmol})$ in isopropanol $(30 \mathrm{~mL})$ was stirred at room temperature for $3 \mathrm{~h}$. The formed solid product was filtered, recrystallized with ethanol/hexane and dried as $\mathbf{5 c}$.

5c: Yield: $70 \%$. m.p. $199-201{ }^{\circ} \mathrm{C} .{ }^{1} \mathrm{H}$ NMR (DMSO- $\left.d_{6}\right)$ : 8.95 (s, br, 1H), 5.55(s, br, 2H), 3.81(m, 1H), 1.62(m, 2H), $0.91(\mathrm{t}, 3 \mathrm{H}, J=7.6 \mathrm{~Hz}) ;{ }^{13} \mathrm{C}$ NMR (DMSO- $\left.d_{6}\right) \delta: 172.4,161.2$,
155.8, 56.5, 25.8, 9.8; IR (KBr, $\left.v_{\max }, \mathrm{cm}^{-1}\right): 3401,3394,1620$, 1598, 1545; MS (m/z): 168, 167, 140, 135.

5e: Yield: $63 \%$. m.p. $152-154{ }^{\circ} \mathrm{C} .{ }^{1} \mathrm{H}$ NMR (DMSO- $\left.d_{6}\right)$ : 10.65 (s, br, 1H), 8.92(s, br, 1H), 7.37-7.12(m, 5H), 4.15(m, $1 \mathrm{H}), 2.89-280(\mathrm{~m}, 2 \mathrm{H}) ;{ }^{13} \mathrm{C}$ NMR (DMSO- $\left.d_{6}\right) \delta: 172.1,161.0$, 156.1, 138.5, 129.1, 128.0, 126.1, 56.7, 38.7; IR (KBr, $v_{\max }$, $\left.\mathrm{cm}^{-1}\right): 3325,3314,2972,2925,1640,1542,1450 ;$ MS (m/z): 230, 229, 202, 170, 142, 99, 91.

Synthesis of 3-amino-2-cyanoimino-5-alkyl-tetrahydroimidazol-4-one (4): A solution of 2 (1.8 mmol) and hydrazine $(2.5 \mathrm{mmol})$ in ethanol $(20 \mathrm{~mL})$ was stirred at room temperature for $5 \mathrm{~h}$. The formed precipitate was collected by filtration, washed with ether and dried as 4 . This product was dissolved in isopropanol $(20 \mathrm{~mL})$ and heated under reflux to give 5 .

4b: Yield: $73 \%$. m.p. $153-155^{\circ} \mathrm{C} .{ }^{1} \mathrm{H}$ NMR (DMSO- $d_{6}$ ): 9.65 (s, br, 1H), 5.2(s, br, 2H), 4.23(q, 1H, $J=7.2 \mathrm{~Hz}), 1.25(\mathrm{~d}$, $3 \mathrm{H}, J=7.2 \mathrm{~Hz}$ ) ${ }^{13} \mathrm{C}$ NMR (DMSO- $\left.d_{6}\right) \delta: 173.2,161.6,115.5$, 52.4, 16.4; IR $\left(\mathrm{KBr}, v_{\max }, \mathrm{cm}^{-1}\right): 3335,3296,3175,2190$, 1765,1664; MS (m/e): 154, 153, 125, 110, 94, 69, 67.

4c: Yield: $82 \%$. m.p. $133-135^{\circ} \mathrm{C} .{ }^{1} \mathrm{H}$ NMR (DMSO- $d_{6}$ ): 9.66 (s, br, 1H), 5.12(s, br, 2H), 4.20(t, 1H, J=6.0Hz), 1.72(m, $2 \mathrm{H}), 0.91(\mathrm{t}, 3 \mathrm{H}, J=7.4 \mathrm{~Hz}) ;{ }^{13} \mathrm{C} \mathrm{NMR}$ (DMSO- $\left.d_{6}\right) \delta: 172.6$, 162.1, 115.5, 57.4, 28.6, 9.1; IR (KBr, $\left.v_{\max }, \mathrm{cm}^{-1}\right)$ : 3412, 3179 , 3162, 3043, 2189, 1767, 1663, 1480; MS (m/z): 168, 167, 140, 124.

Synthesis of aminotriazoles isomers (6) and (7): A solution of $2 \mathbf{c}(1.9 \mathrm{mmol})$ and methylhydrazine $(2.3 \mathrm{mmol})$ in isopropanol was heated to reflux for $8 \mathrm{~h}$. The solvent was removed by evaporation and the residue was then chromatographed on silica gel, eluting with chloroform, $20 \%$ ethanol, to give $\mathbf{6 c}$ as an oil $(63 \%)$ and $7 \mathbf{c}(12 \%)$.

6c: Yield: $63 \%$. An oil. ${ }^{1} \mathrm{H}$ NMR $\left(\mathrm{CDCl}_{3}\right): 4.75(\mathrm{~d}, 1 \mathrm{H}, \mathrm{J}$ $=12.1 \mathrm{~Hz}), 4.32(\mathrm{~m}, 1 \mathrm{H}), 3.69(\mathrm{~s}, 3 \mathrm{H}), 3.37(\mathrm{~s}, 3 \mathrm{H}), 1.90(\mathrm{~m}$, $2 \mathrm{H}), 0.91(\mathrm{t}, 3 \mathrm{H}, J=7.6 \mathrm{~Hz}) ;{ }^{13} \mathrm{C} \mathrm{NMR}\left(\mathrm{CDCl}_{3}\right) \delta: 174.1$, 159.5, 152.8, 57.6, 52.3, 32.6, 25.7, 10.2; IR $\left(\mathrm{CHCl}_{3}, \mathrm{v}_{\max }\right.$, $\left.\mathrm{cm}^{-1}\right): 3364,3022,2960,1733,1611,1543,1425,1204 ; \mathrm{MS}$ $(\mathrm{m} / \mathrm{z}): 214,213,181,154$.

6e: Yield: $58 \%$. An oil. ${ }^{1} \mathrm{H}$ NMR $\left(\mathrm{CDCl}_{3}\right): 7.28(\mathrm{~m}, 8 \mathrm{H})$, $6.98(\mathrm{~m}, 2 \mathrm{H}), 5.13(\mathrm{~d}, 1 \mathrm{H}, J=12.1 \mathrm{~Hz}), 4.78(\mathrm{~s}, 2 \mathrm{H}), 4.35(\mathrm{~m}$, 1H), 3.69(s, br, 2H), 3.36(s, 3H), $2.34(\mathrm{~m}, 2 \mathrm{H}) ;{ }^{13} \mathrm{C} \mathrm{NMR}$ $\left(\mathrm{CDCl}_{3}\right) \delta: 172.5,159.7,153.1,135.6,134.9,129.2,128.4$, 128.3, 66.8, 57.2, 37.8, 31.4; IR $\left(\mathrm{CHCl}_{3}, \mathrm{v}_{\max }, \mathrm{cm}^{-1}\right): 3400$, 2979, 1734, 1621, 1545, 1502, 1418, 1271; MS (m/z): 352, 351, 260, 216, 91.

7c: Yield: $12 \%$. m.p. $133-135^{\circ} \mathrm{C} .{ }^{1} \mathrm{H}$ NMR (DMSO- $\left.d_{6}\right)$ : $4.78(\mathrm{~d}, 1 \mathrm{H}, J=12.1 \mathrm{~Hz}), 4.28(\mathrm{~m}, 1 \mathrm{H}), 3.82(\mathrm{~s}, \mathrm{br}, 2 \mathrm{H}), 3.65(\mathrm{~s}$, $3 \mathrm{H}), 3.28(\mathrm{~s}, 3 \mathrm{H}), 1.89(\mathrm{~m}, 2 \mathrm{H}), 0.89(\mathrm{t}, 3 \mathrm{H}, J=7.6 \mathrm{~Hz}) ;{ }^{13} \mathrm{C}$ NMR (DMSO- $\left.d_{6}\right) \delta$ : 173.8, 159.4, 152.8, 57.6, 52.3, 32.6, 25.7, 9.8; IR (KBr, $\left.v_{\max }, \mathrm{cm}^{-1}\right): 3406,3165,1726,1638,1598$, 1545, 1519, 1181; MS (m/z): 214, 213, 181, 154.

7e: Yield: $27 \%$. m.p. $124-126^{\circ} \mathrm{C} .{ }^{1} \mathrm{H}$ NMR (DMSO- $\left.d_{6}\right)$ : $7.25(\mathrm{~m}, 8 \mathrm{H}), 6.99(\mathrm{~m}, 2 \mathrm{H}), 5.22(\mathrm{~d}, 1 \mathrm{H}, J=12.1 \mathrm{~Hz}), 5.02(\mathrm{~s}$, $2 \mathrm{H}), 4.70(\mathrm{~s}, \mathrm{br}, 2 \mathrm{H}), 4.54(\mathrm{~m}, 1 \mathrm{H}), 3.25(\mathrm{~s}, 3 \mathrm{H}), 2.35(\mathrm{~s}, 2 \mathrm{H})$; ${ }^{13} \mathrm{C}$ NMR (DMSO- $d_{6}$ ) $\delta: 173.2,159.6,153.6,136.3,135.5$, 129.2, 128.3, 128.1, 126.7, 66.5, 56.9, 38.4, 32.8; IR (KBr, $\left.V_{\max }, \mathrm{cm}^{-1}\right): 3405,3167,1728,1634,1592,1545,1520,1181$; $\operatorname{MS}(\mathrm{m} / \mathrm{z}): 352,351,260,216,91$. 


\section{RESULTS AND DISCUSSION}

Generally, methods for the synthesis of aminotriazole ring could be divided in two groups according to the starting material. The first group makes use $\mathrm{N}$-cyanoimidates ${ }^{11-13}$ bearing in their structure three atoms $\mathrm{C}-\mathrm{N}-\mathrm{C}$ which could be prepared from cyanamide and orthoesters. The second group comprises the reaction of isothiocyanate with sodium hydrogencyanamide ${ }^{14}$. In the both cases they react with synthons introducing to that structure another two nitrogen atoms (hydrazine or their derivatives).

Indeed, the bis electrophilic character of easily accessible N-cyano-N'(alcoxycarboxylalkyl)thioimidates $\mathbf{2}$ would allow to postulate that their reaction with the hydrazine derivatives could constitute an easy access to new series of 5-amino-1,2,4triazoles 3.

The synthetic pathways depicted in Schemes I-IV outlines, the chemistry of the present study. Thus the starting material methyl N-cyano-N'(alcoxycarboxylalkyl)thioimidates $\mathbf{2}$ are easily prepared in good yield following the reaction of dimethyl N-cyanodithioiminocarbonate with $\alpha$-aminoesters 1 (Scheme-I)

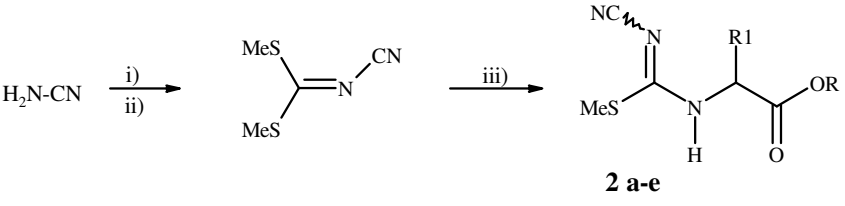

i: $\mathrm{CS}_{2} / \mathrm{EtOH} / \mathrm{KOH}, \quad$ ii: $2 \mathrm{CH}_{3} \mathrm{I} / \mathrm{EtOH}$, iii: $\mathbf{1} \mathrm{H}_{2} \mathrm{~N}-\mathrm{CH}\left(\mathrm{R}^{1}\right)-\mathrm{CO}_{2} \mathrm{R}$. HCl, TEA, reflux / EtOH, $5 \mathrm{~h}$

\begin{tabular}{cllc}
\hline Compounds 2 & $\mathrm{R}$ & $\mathrm{R}^{1}$ & Yield (\%) \\
\hline 2a & $\mathrm{Me}$ & $\mathrm{H}$ & 66 \\
2b & $\mathrm{Me}$ & $\mathrm{Me}$ & 72 \\
$\mathbf{2 c}$ & $\mathrm{Me}$ & $\mathrm{Et}$ & 63 \\
$\mathbf{2 d}$ & $\mathrm{CH}_{2}-\mathrm{Ph}$ & $\mathrm{Et}$ & 67 \\
2e & $\mathrm{CH}_{2}-\mathrm{Ph}$ & $\mathrm{CH}_{2}-\mathrm{Ph}$ & 49 \\
\hline
\end{tabular}

Scheme-I
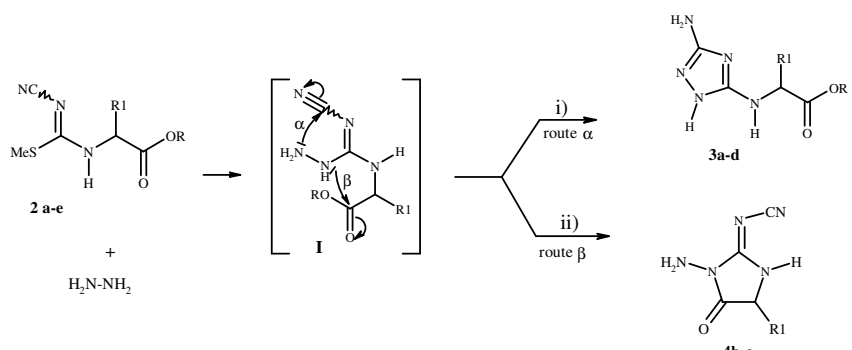

$\begin{array}{ll}\text { i) } \mathrm{iPr}-\mathrm{OH} / \text { reflux, } 7 \mathrm{~h} & \text { ii) EtOH, rt, } 5 \mathrm{~h}\end{array}$

\begin{tabular}{|c|c|c|c|}
\hline Compounds $\mathbf{3}$ & $\mathrm{R}$ & $\mathrm{R}^{1}$ & Yield (\%) \\
\hline $3 \mathbf{a}$ & $\mathrm{Me}$ & $\mathrm{H}$ & 92 \\
\hline $3 b$ & $\mathrm{Me}$ & $\mathrm{Me}$ & 75 \\
\hline $3 c$ & $\mathrm{Me}$ & $\mathrm{Et}$ & 72 \\
\hline 3d & $\mathrm{CH}_{2}-\mathrm{Ph}$ & Et & 65 \\
\hline $3 e$ & $\mathrm{CH}_{2}-\mathrm{Ph}$ & $\mathrm{CH}_{2}-\mathrm{Ph}$ & 68 \\
\hline Compounds 4 & & $\mathrm{R}^{1}$ & Yield (\%) \\
\hline $4 b$ & & $\mathrm{Me}$ & 73 \\
\hline $4 c$ & & $\mathrm{Et}$ & 82 \\
\hline
\end{tabular}

Scheme-II
The reaction of $\mathbf{2}$ with hydrazine was assumed to proceed by substitution of the methylthio group of $\mathbf{2}$ with hydrazine giving the intermediate $\mathrm{N}$-cyanoguanidine (I), which could be cyclize via the nucleophilically competitive attack of hydrazine group to nitrile to give 5-aminotriazoles 3 or to ester function leading to the formation of aminoimidazolones 4 .

The structure of compounds $\mathbf{3}$ was established on the basis of their spectral data. Thus structure 3 is supported by their ${ }^{1} \mathrm{H}$ NMR and IR spectra; the latter showed the disappearance of $\mathrm{CN}$ band at $2200 \mathrm{~cm}^{-1}$.

When the reaction of $\mathbf{2}$ with hydrazine was carried out at room temperature in ethanol, good yields of imidazolones 4 was obtained.

In further experiments after compound $\mathbf{4}$ had been formed at $25^{\circ} \mathrm{C}$, isopropanol was added and the reaction mixture was heated to reflux. The NMR and IR spectra of the new product showed that it was the bicyclic tetraazaoctanone $\mathbf{5}$.

The bicyclic compound $\mathbf{5}$ can also be prepared by the reaction of $\mathbf{2}$ with hydrazine at room temperature in isopropanol during $3 \mathrm{~h}$.

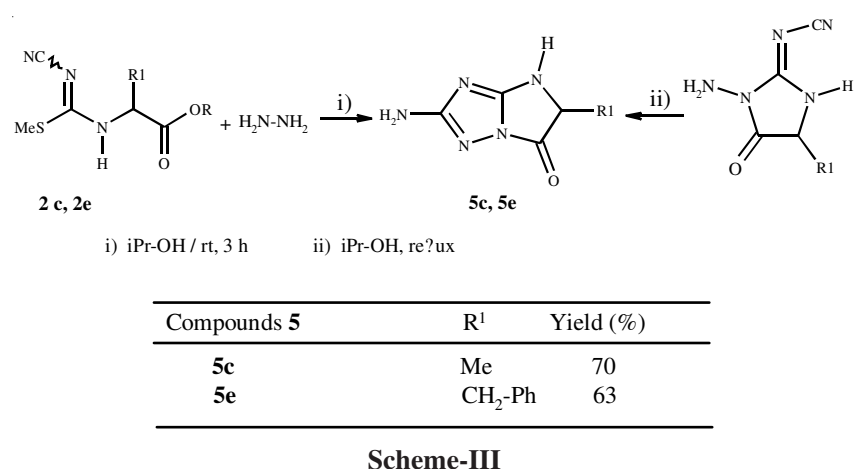

When the compounds $\mathbf{2} \mathbf{c}$ and $\mathbf{2 e}$ were treated with excess of methylhydrazine in refluxing isopropanol, a mixture of two readily separable products 6 and 7 were formed, neither of them bicyclic.

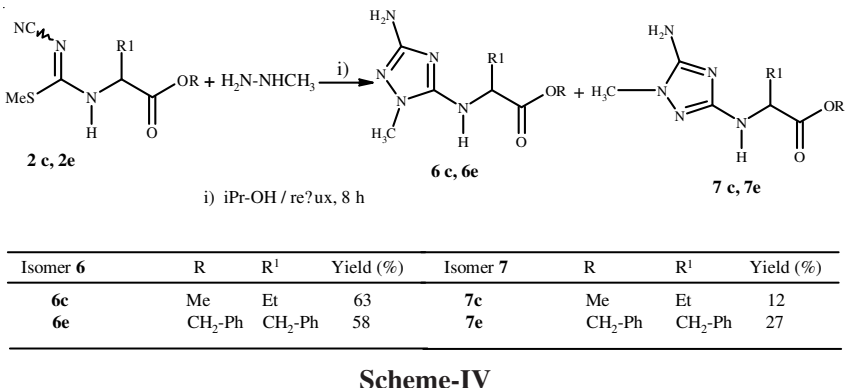

In this nucleophilic addition step of methylhydrazine, the regioselectivity for the reaction sequence was controlled by kinetics, through in all cases isomer 6 was formed in preference to isomer 7. This moderate regioselectivity in favour of 6 can probably be understood by considering that the substituted nitrogen of hydrazine may have the greater electron density when compared to the unsubstituted nitrogen because of the electrodonating of methyl group. These regioisomers were distinguished by Nuclear Overhauser Effect (NOE) experiments. 
So, that irradiation of methyl group protons in $\mathbf{6}$ caused enhancement of the NH, but NOE in (7) was observed between $\mathrm{NH}_{2}$ and $\mathrm{N}$-methyl group protons (Scheme-V).<smiles>Nc1nc(N2CCCCCCCCCCC2)n(C([Al])C(=O)O)n1</smiles><smiles>CC(Nc1nc(NCCCO)n(C)n1)C(=O)O</smiles>

7

Scheme-V

Antimicrobial activity: The synthesized compounds 3a$\mathbf{e}, 5 \mathbf{c}, 5 \mathbf{e}, \mathbf{6 c}$ and $\mathbf{6 e}$ were tested for their in vitro antimicrobial activity against the gram positive bacteria Staphylococcus aureus (S. aureus), gram negative bacteria Pseudomonas aeruginosa ( $P$. aeruginosa), Escherichia coli (E. coli) and the fungus Aspergillusniger (A. niger). Standard drugs like ampicillin and griseofulvin were used for the comparison purpose. The antimicrobial was assayed by using the agar disc-diffusion method ${ }^{15,16}$. The results are summarized in Table-1.

\begin{tabular}{|c|c|c|c|c|}
\hline & $\begin{array}{r}\mathrm{T} \\
\text { TIMICROBIAL } \\
\text { COMPOUNDS }\end{array}$ & $\begin{array}{l}\text { E-1 } \\
\text { REENIN } \\
\text { e, } \mathbf{5 c}, \mathbf{5 e}\end{array}$ & $\begin{array}{l}\text { ESULTS } \\
\text { AND 6e }\end{array}$ & \\
\hline & Diameter & owth inl & tion zone ( 1 & \\
\hline Compound & Antibacteric & ivity & Antifung & activity \\
\hline & P. aeruginosa & E. coli & S. aureus & A. niger \\
\hline $3 a$ & 9 & 11 & 10 & - \\
\hline $3 b$ & 11 & 9 & 12 & - \\
\hline $3 c$ & 5 & 7 & 5 & - \\
\hline 3d & 13 & 8 & 11 & - \\
\hline $3 e$ & 10 & 10 & 12 & - \\
\hline $5 c$ & 11 & - & 13 & 11 \\
\hline $5 e$ & 12 & - & 12 & 13 \\
\hline $6 c$ & 11 & - & - & - \\
\hline $6 e$ & 13 & 12 & 13 & - \\
\hline Griseofulvin & - & - & - & 24 \\
\hline Ampicillin & 15 & 22 & 19 & - \\
\hline
\end{tabular}

Antibacterial activity results have revealed that synthesized triazoles 3a-e, $\mathbf{6 c}$ and $\mathbf{6 e}$ showed no antifungal activity against the $A$. niger tested organisms. However the bicyclic compounds have shown average antifungal activity in compa- rison to antifungal drug griseofulvin. The majority of the synthesized triazoles showed varying degrees of inhibition against all the tested bacteria.

On the other hand the best antibacterial activity was displayed by the triazole $\mathbf{6 e}$ and the Gram negative bacteria Pseudomonas aereuginosa is considered the most sensitive among the tested organisms.

\section{Conclusion}

An efficient synthetic route was developed for the synthesis of 5-amino-1,2,4-triazoles and their bicyclic system starting from a-aminoesters, hydrazine derivatives and dimethyl N-cyanodithioiminocarbonate. The new structures of the prepared compounds were established on the basis of their spectral data and were tested for in vitro antimicrobial activities. None of the triazoles $\mathbf{3 a - e , ~} \mathbf{6 c}$ and $\mathbf{6 e}$ were proved to be significantly active against $A$. niger.

\section{REFERENCES}

1. K. Sztanke, T. Tuzimski, J. Rzymowska, K. Pasternak and M. KanderferSzerszen, Eur. J. Med. Chem., 43, 404 (2008).

2. B.S. Holla, K.N. Poojary, B.S. Rao and M.K. Shirananda, Eur. J. Med. Chem., 37, 511 (2002).

3. I.R. Ezabadi, C. Camoutsis, P. Zoumpoulakis, A. Geronikaki, M. Sokovic, J. Glamocilija and A. Ciric, Bioorg. Med. Chem., 16, 1150 (2008).

4. S. Kumari, K. Nitin, D. Sushma and K.S. Promod, J. Org. Chem., 7, 668 (2011).

5. A.A. Siddiqui, M. Ul Islam and N. Siddiqui, Asian J. Chem., 16, 534 (2004).

6. N.S. Vatmurge, B.G. Hazra, V.S. Pore, F. Shirazi, P.S. Chavan and M.V. Deshpande, Bioorg. Med. Chem. Lett., 18, 2043 (2008).

7. B.S. Holla, M. Mahalinga, M.S. Karthikeyan, B. Poojary, P.M. Akberali and N.S. Kumari, Eur. J. Med. Chem., 40, 1173 (2005).

8. G.M. Gonzalez, A.W. Fothergill, P.A. Sutton, M.G. Rinalldi and D. Loebenberg, Med. Mycol., 43, 281 (2005).

9. R.J. Singh and D.K. Singh, Asian J. Chem., 22, 2659 (2010).

10. G. Turan-Zitouni, Z.A. Kaplancikli, M.T. Yildiz, P. Chevallet and D. Kaya, Eur. J. Med. Chem., 40, 607 (2005)

11. D. Thomae, E. Perspicace, S. Hesse, G. Kirsch and P. Seck, Tetrahedron, 64, 9309 (2008).

12. M.O. M'hamed, H. M'rabet and M.L. Efrit, Compt. Rend. Chimie, 10, 1147 (2007).

13. A. Zarguil, S. Boukhris, M.L. El Efrit, A. Souizi and E.M. Essassi, Tetrahedron Lett., 49, 5883 (2008).

14. V.M. Chernyshev, V.A. Rakitov, V.V. Blinov, V.A. Tranushich and Z.A. Starikova, Chem. Heterocycl. Comp., 45, 436 (2009).

15. National Committee for Clinical Laboratory Standards (NCCLS), Approved standard document M7A, Villanova, PA, USA (1985).

16. R. Nair, T. Kalariya and S. Chanda, Turk J. Biol., 29, 41 (2005). 